\title{
Purchasing efficiency in a mining food service organisation
}

\author{
Wilna H Oldewage-Theron *, H Salome Kruger ** \\ and L Reinier Jansen van Rensburg ***
}

\begin{abstract}
OPSOMMING
Aankope sluit 'n reeks aktiwiteite in wat die keuse en verkryging van verlangde kommoditeite of dienste tot gevolg het. Die primêre doel van hierdie navorsing was om die effektiwiteit en doeltreffendheid van die sentrale aankoopafdeling wat vir die voedselaankope van 35 mynvoedseldienseenhede verantwoordelik is te meet voor en nadat 'n prosedurehandleiding geïmplementeer is. 'n Ander doelwit was om misverstande tussen aankopers en leweransiers op te los deur voedselspesifikasies en 'n gestandaardiseerde tenderdokument te ontwikkel en te implementeer.
\end{abstract}

Die metodologie sluit eenheidsbesoeke, vraelyste en die toepassing van sekere kriteria vir die meet van aankoopdoeltreffendheid en -effektiwiteit in. Daar is ' $n$ prysoorlog in die mynindustrie en dit is belangrik om koste te besnoei om mededingend te kan bly. Om hierdie rede is koste en prysverhogings as die hoofkriteria by die meting van effektiwiteit gebruik.

Die resultate in hierdie studie dui daarop dat die sentrale aankoopafdeling baie effektief was aangesien prysverhogings laer as die inflasiekoers was. Hierdie laer prysverhogings kan ook aan die implementering van die voedselspesifikasies toegeskryf word. Die navorsing het ook bewys dat minder misverstande voorkom wanneer voedselspesifikasies en 'n gestandaardiseerde tenderdokument gebruik word. Dit dra by tot beter beheer en bestuur deur 'n sentrale aankoopafdeling.

-Ms WH Oldewage-Theron *

Department of Food

Vaal Triangle Technikon

- Ms HS Kruger **

Department of Nutrition and Family Ecology

Potchefstroom University for Christian Higher Education

- Prof LR Jansen van Rensburg ***

School for Business Management

Potchefstroom University for Christian Higher Education

\section{INTRODUCTION}

Until comparatively recently purchasing in most organisations was considered a relatively unimportant function (Baily et al, 1994:5). During the seventies in particular businesses started showing an increasing interest in the purchasing function, recognising the importance and significance of a developed purchasing and supply function (Baily et al, 1994:5; Hugo et al, 1997:10).

Purchasing is an ever-changing, dynamic part of the daily food service operation (Baily et al, 1994:5; Kotschevar \& Donnelly, 1994:vii). It is an essential function in the system as it is the first step in the production and service of quality food. Although the procurement process for all types of food service units, whether institutional or commercial, involves food, major emphasis is given to the buying of food (PaynePalacio \& Theis, 1997:116). The goal of any foodservice is, however, to serve quality meals while maximising value for both the operation and the customer (Spears, 1995:202).

Purchasing includes a series of activities for the selection and acquisition of desired commodities and/or services. Important aspects to deal with are procedures for the selection and evaluation of suppliers, determining food needs, and writing food specifications (Kotschevar \& Donnelly, 1994:2). These procedures should be standardised, especially in view of the severe price competition in the mining food service industry. Costs have to be curtailed in order to stay competitive (Watkins, 1995:30).

Two important steps in any purchasing programme is to establish food specifications and a list of suppliers from whom the operators are to purchase. Specifications are important because they serve as a main communication link between the buyer and the seller. Specifications may actually be considered the "heart of purchasing" (Kotschevar \& Donnelly, 1994:34). A list of reliable suppliers is important to ensure that the buying organisation operates effectively.

A food specification is a detailed description of a product, stated in terms that are clearly understood by both the supplier and the buyer (Payne-Palacio \& Theis, 1997). Such a specification may be defined as a precise, formal statement of all the characteristics of a product to fill specific production needs (Stefanelli, 1992:99). Brief, but concise, specifications could contain enough information to obviate any misunderstanding (Payne-Palacio \& Theis, 1997:139; Watkins, 
1995:30). However, these specifications should be realistic and not unattainable, fair to the supplier and protective of the buyer (Spears, 1995:222).

Experience has shown that the following may be expected when specifications are used: lower cost, improved product quality, better organised purchasing, fewer misunderstandings between the buyer and the seller, more effective negotiation, time saving, limited stockouts, and standardised training of employees. Clients are more satisfied and management control improves (Kotschevar \& Donnelly, 1994:35; Stefanelli, 1992:100).

Purchasing performance is directly influenced by factors that are external to the purchasing function and others that are inherent in the purchasing function (Hugo \& van Rooyen, 1990:290). Purchasing managers have to ensure that the measures they apply are reliable and valid because of extensive problems in evaluating the performance of the purchasing function. A wide range of measures should be used, if possible, to obtain a comprehensive overview for the actual performance of the purchasing function.

\section{PROBLEM STATEMENT AND AIM OF THE PROJECT}

The purchasing function is characterised by a large number of diverse activities and various purchasing functionaries are responsible for these activities. It is therefore difficult to build an objective overall picture of their purchasing performance. It is also difficult to express the performance of various purchasing activities in qualitative terms. Negotiation with and development of supplier relationships are examples. The intangibility of purchasing performance inevitably introduces a degree of subjectivity to the actual evaluation of performance. Most performance standards cover purchasing performance, but make no provision for direct measurement of such performance (Hugo \& van Rooyen, 1990:290).

The aim of this project was to measure purchasing efficiency in the central purchasing department of an industrial mining catering company with 35 mine kitchens before and after the provision of a food specification manual to be used with the tender documents. Measurement included measures of purchasing efficiency before and after the implementation of standardised tender documents. The following steps were followed:

- Step 1: Identifying the food purchasing needs of 35 food service mining units and determining the supplier inventories used for supply to the food service organisation

- Step 2: Compiling questionnaires for the food service managers and suppliers

- Step 3: Developing food specifications for the desired food products

- Step 4: Modifying the tender document

- Step 5: Selecting appropriate suppliers to compete in the formal competitive bid

- Step 6: Measuring purchasing efficiency.

\section{PROCEDURES}

\section{Introduction}

Since no data on similar studies could be found in the literature, the researcher consulted the purchasing general manager at the mining food service organisation as well as study leaders about an appropriate methodology. The research methodology decided upon was action research, as a cyclical, active process would be developed during the research period. Planning, implementation and evaluation would constantly take place. Although the research was performed within a planned framework, new decisions were made throughout the research period.

Step 1: Identifying the food purchasing needs of the $\mathbf{3 5}$ mining food service units and determining the supplier inventories for supplies to the food service organisation

Visits to food service units All 35 mining food service units were visited. The objectives and content of the research project were explained to the catering managers. They were also informed about the methodology that would be used and the questionnaires that would be sent to them. The importance of completing these questionnaires was explained to them.

During these visits information was collected on the type, quality and quantity of the food items ordered from the existing tender document by each food service unit. A list was drawn up of items that did not appear on the tender document, and all authorised as well as unauthorised suppliers used by the catering managers were listed. The reasons for using unauthorised suppliers were recorded.

The following informal observations were made during these visits:

- Due to a lack of detailed food specifications, the wrong items were placed on the tender documents and cash and unauthorised purchases were made to acquire the products that were needed. This resulted in a loss of discount income as well as higher prices, as volumes were not taken into consideration in price determination.

- Unnecessary administrative problems existed between the authorised suppliers and the catering managers because the number of deliveries per week had not been determined during previous tender processes.

Visits to suppliers All the suppliers were asked to indicate which of the items on the existing tender document they could supply.

When the food specifications for the previous tender document and the information supplied by the catering managers and suppliers were compared, the following were observed:

- The portion sizes of especially the meat, poultry and fish required by the catering managers differed from those on the tender document. 
- The type of maize meal on the tender document was not necessarily the type used by the catering managers. The tender document did not include special maize meal, and two geographical areas, namely Rustenburg and Witbank, required special maize meal. The pack size of $80 \mathrm{~kg}$ on the tender document was incorrect. Most enriched maize meal pack sizes were $50 \mathrm{~kg}$ or $61 \mathrm{~kg}$.

- Most catering units used processed vegetables and the monthly consumption volumes on the tender document applied to fresh products.

- The tender document did not make provision for tea or coffee urn bags and the catering managers required different sizes. Only tea and coffee co-mixes were provided for by the tender document.

- The bread pack specifications were not available in the previous tender document and this caused many problems.

- The milk containers have never been specified and certain units needed specific packaging and pack sizes. For example, only the 20 Pak-o-Milk was available on the tender document for a specific geographical area which also needed 1 containers.

Step 2: Compiling questionnaires for the food service managers and suppliers

A questionnaire that encompassed the information gathered in Step 1 was compiled and sent to 35 catering managers and 49 suppliers. The questionnaire covered the following:

- Description of food items

- Quality (grade, class, size)

- Brand names

- Portion sizes

- Pack sizes

- Quantity per kilogram or pack

- Price per kilogram

- Packaging material

- Packaging type

- Number of deliveries per week

- Fresh, frozen or dried.

The same questionnaire was completed by both the catering managers and the suppliers. A $100 \%$ response was obtained from the catering managers. They supplied the monthly product volume consumption as well as food specifications. However, they were unable to give details about packaging requirements.

Details of the monthly purchasing volume analysis (PVA) of the mining food service units were compared. Ratios were calculated as a mean for the 35 mining food service units. When these figures were compared, it was clear that the products that should be a determining factor in negotiating prices were beef portions with bone for meat, mine cut portion (MCP) chicken for poultry, hake number six for fish products, maize meal for dry goods items, brown bread and bread packs for bread, apples for fruit, and potatoes and cabbage for vegetables.

The information collected from the suppliers included the following:

- Food service units they supplied

- Frequency of deliveries per week or month

- Type of products supplied to the food service units

- Detailed specifications of these products

- Monthly purchasing volumes per product supplied in rand value as well as weight or volume

- Amount of money the units spent per month.

Only 39 of the 49 suppliers $(79,6 \%)$ responded. Their ability to deliver items to different areas was determined as well as their problems with supplying food items. The other suppliers were contacted and asked for their responses, but they were unwilling as they could not supply the necessary information. These suppliers mostly supplied fresh produce and dry goods. They did not keep statistics for individual catering units and statistics could only be supplied for total purchases, including industrial catering units not covered by the tender process. The fresh produce suppliers could not supply monthly volumes as they only kept records of total purchases per month per geographical area. These purchases included a variety of products and no individual product sales data were available. Price variations were common due to market fluctuations.

Of the 39 suppliers who responded, only 7 (14,3\%) could provide the information required on the questionnaires. The other 32 suppliers $(65,3 \%)$ also did not keep separate statistics per catering unit and could only supply monthly consumption values for the organisation as a whole (not only for the mining division). The information supplied by the suppliers could therefore not be used for comparisons of monthly volumes between suppliers and catering units.

All 39 suppliers $(79,6 \%)$ who responded to the questionnaires supplied the required information on food specifications. The 10 who did not respond were contacted but were unable to supply information. The dry goods suppliers had a stock range of 4000 different types of products and could not differentiate with regard to food specifications as they acted as distributors only and were not the manufacturers. Three of the fresh produce suppliers supplied information regarding pack sizes, type of packaging and the specifications of some of the fresh produce items.

\section{Step 3: Developing food specifications for the desired food items}

After Step 2 the food service organisation decided that only items with a consumption volume in excess of 100 $\mathrm{kg}$ per month had to be included in the specification document that was to accompany the tender document, and that a questionnaire covering those items had to be drawn up. The relevant information for each type of product was determined for the questionnaire. The criteria included in the specifications were pack size, quantity supplied per month (weight or volume), quantity supplied per month (rand value), packaging type and material, and number of deliveries per week. Specific criteria were included for each type of product, based on the guidelines set by Kotschevar and Donnelly (1994:37). 
According to the product volume analysis, the rand value the food service organisation spent on food items per month was as follows: $24,0 \%$ on meat, $25,0 \%$ on frozen items, $7,2 \%$ on fresh fruit and vegetables, $1,8 \%$ on eggs, $2,6 \%$ on other dairy products, $3,0 \%$ on sorghum and mageu, $9,1 \%$ on bread and confectionery, $23,2 \%$ on dry goods, and $4,1 \%$ on other items. The central purchasing department of the organisation decided that only perishable products, excluding dairy products, should be included in the food specification manual as all other dry goods and dairy items are regulated by legislation. Specifications were then drawn up for fresh meat, processed meat, fish, poultry, fresh vegetables and fruit, processed vegetables, bread and confectionery.

One of the fresh produce suppliers as well as a meat supplier and a bakery were visited to determine existing pack sizes and packaging type and to take pictures of all the fruit, vegetable, meat and bakery products that were used. The specification format was then decided upon and all the information was collated and typed. The photographs were scanned into the specifications.

\section{Step 4 : $\quad$ Modifying the tender document}

After the detailed food specifications were developed, the tender document was drawn up and sent to the suppliers for the next tender period, namely 1 August 1997 to 31 January 1998. The tender document contained specifications for all the food commodities with a consumption of more than $100 \mathrm{~kg}$ per month:

- Fresh meat (for example chuck, Grade C, sliced, $20 \%-30 \%$ bone, 210 g portion)

- Processed meat (for example bacon, Grade 1, $3 \mathrm{~mm}$ diameter rashers, rindless, vacuum-packed)

- Fish (for example hake fillets, flesh on either side of the backbone and bones of the thoracic cavity, skin off, $150 \mathrm{~g}$ )

- Poultry (for example MCP portion, Grade B, frozen, chicken cut into six pieces of $\pm 200 \mathrm{~g}$ each)

- Dairy products (for example full-cream milk, 3,3\% milk fat, $3,8 \%$ milk solids, 1 plastic sachet)

- Mageu and sorghum (for example flavoured, 20 carton)

- Dry goods (for example maize meal, sifted, white maize, $81 \mathrm{~kg}$ paper bag)

- Bread and confectionery (for example bread packs, $80 \%$ white and $20 \%$ brown, with $15 \mathrm{~g}$ margarine, sealed in polyethylene bag)

- Fresh vegetables (for example butternut, $\pm 400 \mathrm{~g}$ $500 \mathrm{~g}$ each, $300 \mathrm{~mm} \times 375 \mathrm{~mm} \times 200 \mathrm{~mm}-250 \mathrm{~mm}$, packed in $5 \mathrm{~kg}$ wooden crate)

- Fresh fruit (for example bananas, Grade 1, large, $120 \mathrm{~g}-130 \mathrm{~g}$ each, $\pm 180 \mathrm{~mm}$ in circumference, neither overripe nor green, free of bruises, sun damage or decay, bunches packed in $22 \mathrm{~kg}$ carton box)

- Processed vegetables (for example gems, $\pm 200 \mathrm{~g}$ each, $70 \mathrm{~mm}-90 \mathrm{~mm}$ diameter, halved, pips removed, clean, fresh, firm, not overripe, vacuumpacked).

Additional information for each item to be furnished by the suppliers included a description of the item, packaging type and size, quantity per delivery, geographical area, and price per kilogram or pack.

Determining geographical areas The location and size of the food service units are important factors in selecting suppliers. If the operation is located in or near a large metropolitan area, several suppliers could meet the quantity and quality needs, and their delivery schedules would be satisfactory to the food service units. If the operation is in a small or remote location, part or all of its supplies may be purchased locally (Payne-Palacio \& Theis, 1997;125).

As all the food service units in this study were in remote areas, it was decided to group the monthly volume consumption of the 35 food service units into six geographical areas, namely Carletonville (one unit), Welkom (five units), Rustenburg (three units), the Vaal Triangle (one unit), Standerton (one unit), and Witbank-Middelburg (24 units). This would enable the catering managers to purchase dairy products, fresh vegetables, fruit and bread locally.

\section{Step 5: Selecting appropriate suppliers to compete in the formal competitive bid}

Reliability, fairness when quoting prices, cooperation, performance and timely delivery (Payne-Palacio \& Theis, 1997:125) were considered when the current suppliers were evaluated for inclusion in the tender process.

New suppliers who wanted to be included in the process were investigated. Supplier product lists were examined to determine whether they could supply the required products and their customers were contacted to discuss the efficiency of the supplier. Financial statements were requested in order to establish net income during the previous year, profitability, liquidity and solvency. Only suppliers in a sound financial position were invited to tender.

Ninety-seven suppliers were selected to take part in the tender process and tender documents were posted to them for completion by 13 June 1997.

Determining successful tenderers The following criteria were used in selecting suppliers for the new tender period (02/97):

- Price and quality quoted. Products that offered the best value for money were chosen. In all cases the lowest quote was accepted as quality was specified in the tender document.

- Financial stability. The suppliers who were selected to supply the food service units had to be able to carry a thirty-day account.

- Geographical location. The suppliers had to be able to supply to all the mining food service units in a specific geographical area.

- Labour relations. The suppliers' premises are regularly visited by the central purchasing department to ensure that good labour relations are practised (this would ensure continuity of delivery).

- Service. The suppliers' service records were examined to ensure timely delivery.

- Hygiene. The selected suppliers were subjected to a hygiene audit by an independent microbiology laboratory. 
The determining factor in the competitive bidding process was price quoted per tender item per geographical area. Service, quality and quantity were also considered (Kotschevar \& Donnelly, 1994:44)

Two competitive suppliers were allocated per product per geographical area so that all the tenders were allocated as "shared contracts". Commodities were grouped together to limit the number of suppliers in each geographical area. The successful fresh meat supplier was for example also selected to deliver processed meat. More than one geographical area was allocated to the same supplier(s) if it could deliver to both areas. One meat supplier would for example be successful in obtaining the business in two or more geographical areas. This also meant fewer suppliers to be dealt with and bigger discounts due to bigger volumes.

Step 6: Measuring the purchasing efficiency of the central purchasing department of the food service organisation

For the purposes of this study, baseline indices were calculated at the beginning of the research as well as after the modified tender document had been sent to the suppliers. The indices were calculated by combining the information for all 35 catering units because the accounting systems of the organisation and the suppliers could not accommodate 35 separate accounts and treat the mining division as one unit. This unfortunately made it impossible to do a statistical analysis.

The price variance ratio, total price variance, supplier turnover, concentration of negotiating power, and lack of competition were used as measuring factors. All formal measurements were made according to the following formulas to measure purchasing proficiency and efficiency:

Purchasing proficiency Purchasing proficiency was measured in terms of pricing proficiency for maize meal, meat and chicken, supplier performance and competition.

(1) Pricing proficiency indicates the extent to which the purchasing function allowed purchasing to take place at competitive prices.

Price variance ratio $=$ actual price $\div$ planned price

Total price variance $=$ (actual price - planned price $) X$ quantity purchased

\section{(2) Supplier performance}

Supplier performance is an indirect measure of purchasing performance because selection and development of the supply system are deemed to be the primary tasks of the purchasing function. Good supplier performance is therefore an indication of how well the purchasing function performed:

Supplier turnover $=$ number of new suppliers $\div$ total number of suppliers (measured for a tender period of six months)

(3) Competition

Competition as a performance measure explains how proficient the purchasing function is at maintaining and developing competitiveness in the supply system.

Concentration of negotiating power $=$ monetary value of centralised purchasing $\div$ monetary value of overall purchasing

Lack of competition $=$ monetary value of orders placed with one supplier $\div$ monetary value of total purchases

Purchasing efficiency

Purchasing efficiency was measured in terms of cost savings, quantity discount ratio, unauthorised and cash purchases.

(1) Cost savings as a purchasing efficiency measure attempts to depict how efficiently the purchasing function utilises financial resources. Cost savings have two essential elements: cost reduction and cost avoidance. Both focus on measures adopted by the purchasing function to spend less of the available financial resources in carrying out the purchasing function. The following norms were measured:

Cost-avoidance ratio $=$ (actual purchase price $\mathrm{X}$ quantity purchased) $\div$ (lowest price quoted $\mathrm{X}$ quantity purchased)

Inflation index $=$ actual negotiated price increase $\div$ expected price increase in terms of inflation rate

(2) The quantity discount ratio, unauthorised and cash purchases were measured for a period of six months after implementation of the standardised tender procedures.

Quantity discount ratio $=$ ratio of value of quantity discounts to value of total purchases during current period $\div$ ratio of value of quantity discounts to value of total purchases during successive previous periods Unauthorised purchases $=$ monetary value of unauthorised purchases $\div$ monetary value of total purchases Cash purchases $=$ monetary value of total cash purchases $\div$ monetary value of total purchases

Performance was measured for the six-month period before and after implementation of the new food specifications and tender document (Hugo \& Van Rooyen, 1990; Lysons, 1993: 276).

\section{RESULTS}

\section{Base line indices}

The central purchasing department of the food service organisation used information from the previous tender period to calculate the base line indices. The following results were obtained (see Table 1):

- The food price index (FPI) supplied by the Central Statistics Office was used to calculate the planned prices for the new tender period. A 10,1\% increase was expected as that was the average of the FPI during the previous six-month tender period. However, the MCP portion price was quoted 7,3\% cheaper than in the previous tender period, and the price of beef portions showed no increase. The meat supplier kept his prices fixed during the next 
TABLE 1: PURCHASING PROFICIENCY COMPARED AND MEASURED IN 35 MINING FOOD SERVICE UNITS DURING TENDER PERIODS 01/1997 AND 02/1997

\begin{tabular}{|c|c|c|}
\hline MEASURING FACTOR & $\begin{array}{c}01 / 97 \\
\text { (baseline) }\end{array}$ & $\begin{array}{c}02 / 97 \\
\text { (after } 6 \text { months) }\end{array}$ \\
\hline $\begin{array}{l}\text { PRICE VARIANCE RATIO: } \\
\text { Super maize meal } \\
\text { MCP chicken portions } \\
\text { Beef portions with bone }\end{array}$ & $\begin{array}{r}0,90^{*} \\
1,09 \\
1,04\end{array}$ & $\begin{array}{l}1,09 \\
0,85 \\
0,85\end{array}$ \\
\hline $\begin{array}{l}\text { TOTAL PRICE VARIANCE: } \\
\text { Super maize meal } \\
\text { MCP chicken portions } \\
\text { Beef portions with bone }\end{array}$ & $\begin{array}{l}(\mathrm{R} 924,00)^{*} \\
\text { R64 065,00 } \\
\text { R20 125,00 }\end{array}$ & $\begin{array}{c}\mathrm{R} 840,00 \\
(\mathrm{R} 127275,00)^{*} \\
(\mathrm{R} 62890,00)^{*}\end{array}$ \\
\hline $\begin{array}{l}\text { SUPPLIER PERFORMANCE: } \\
\text { Supplier turnover }\end{array}$ & 0,037 & 0,033 \\
\hline $\begin{array}{l}\text { COMPETITION: } \\
\text { Concentration of negotiating power } \\
\text { Lack of competition }\end{array}$ & $\begin{array}{l}1 \\
0\end{array}$ & $\begin{array}{l}1 \\
0\end{array}$ \\
\hline
\end{tabular}

- $\quad$ Fewer rands spent, ie savings

TABLE 2 PURCHASING EFFICIENCY COMPARED AND MEASURED IN THE CENTRAL PURCHASING DEPARTMENT DURING TENDER PERIODS 01/1997 AND 02/1997

\begin{tabular}{|l|c|c|}
\hline \multicolumn{1}{|c|}{ MEASURING FACTOR } & \multicolumn{1}{|c|}{$\begin{array}{c}\text { FFS 01/97 } \\
\text { (baseline) }\end{array}$} & $\begin{array}{c}\text { FFS 02/97 } \\
\text { (after next 6 months) }\end{array}$ \\
\hline Cost-avoidance ratio: & & 1 \\
Super maize meal & 1 & 1 \\
MCP chicken portions & 1 & 1 \\
Beef portions with bone & & 1,92 \\
\hline Inflation index: & $(1,82)^{*}$ & $(0,67)^{*}$ \\
Super maize meal & 3,74 & $(0,36)^{*}$ \\
MCP chicken portions & 2,09 & 1,12 \\
Beef portions with bone & 1,12 & 0,004 \\
\hline Quantity discount ratio & 0,005 & 0,03 \\
\hline Unauthorised purchases & 0,035 & 12 \\
\hline Cash purchases & & 0 \\
\hline
\end{tabular}

${ }^{*}$ Negative

tender period. The maize price increased by $8,8 \%$. The suppliers clearly had proper specifications and volumes for their price calculations, and the organisation benefited by using a tender document with detailed food specifications.

- MCP chicken and beef portion prices were quoted much lower than expected, which saved on purchasing expenditure. The maize price was quoted higher than expected, however, and expenditure would consequently increase. The total savings in expenditure would nevertheless be R189 325 during the new sixmonth tender period $(02 / 1997$. This was in contrast to the previous tender period when the forecast expenditure had been R83 266 more than planned.

- Supplier turnover remained more or less the same, but fewer suppliers were selected for the new tender period (59 suppliers for tender period 02/1997 compared to 81 for tender period 01/1997). Only two new suppliers were selected for the new tender period, one for poultry and one for meat. 
- Negotiation power is $100 \%$ concentrated in the central purchasing department. There was no lack of competition as two suppliers were chosen for each commodity and shared contracts were allocated.

\section{Purchasing efficiency}

The following results were obtained when purchasing efficiency was measured (see Table 2):

- The inflation index was kept well below the FPI as negative inflation applied to meat and chicken prices.

- Additional costs were avoided as the lowest quoted prices were accepted for the next tender period. This shows that price is very important in the mining food service industry.

- Fewer unauthorised and cash purchases were made due to a proper purchase volume analysis in each geographical area and proper food specifications. The details given to the suppliers were more accurate and the food service managers did not have to purchase items not listed in the tender document. Unauthorised purchases decreased by an average R10 000 per month and cash purchases by an average R5 000 per month. This constituted a meaningful improvement, but should decrease to R0 per month. The modified tender document and the new food specifications thus improved the organisation's bottom-line income.

\section{Summarised results of tender document and food specifications}

The following results may be ascribed to the new tender document and the detailed food specifications:

- A perceived cost saving as the suppliers had access to accurate monthly consumption values for each commodity and could plan accordingly

- Fewer misunderstandings between the buyer and the supplier due to detailed descriptions of the products, the packaging and consumption

- Competitive prices and a competitive service from suppliers

- A time saving because it was unnecessary to do quality checks as grades and classes had been specified

- Overall satisfaction of both food service managers and the central purchasing department as the tender process could proceed without problems.

\section{DISCUSSION}

The study attempted to ascertain the extent to which food specifications would influence the purchasing efficiency and proficiency of a central purchasing department in the mining food service industry. The literature pointed out that purchasing, as a management function, was a complex subject (Kotschevar \& Donnelly, 1994:2; Payne-Palacio \& Theis, 1997:116). Effective purchasing requires a proper needs assessment and detailed food specifications (Kotschevar \& Donnelly, 1994:18; PaynePalacio \& Theis, 1997:117).
Supplier selection is another important step in the purchasing process. Suppliers selected for the mining food service units had to be able to supply goods of the correct quality, quantity and price, when needed by the food service units (Kotschevar \& Donnelly, 1994:43; PaynePalacio \& Theis, 1997:125).

A tender document was modified to accommodate the needs of the food service units in each geographical area. The modified tender document proved that providing detailed information to the suppliers ensured price, quality and service benefits.

One reason why this research was undertaken was to resolve misunderstandings between the suppliers and the food service managers. This was accomplished by revising the tender document to include detailed descriptions of goods, packaging and delivery requirements.

Purchasing efficiency was measured in the central purchasing department. The data in Tables 1 and 2 prove that the central purchasing department was quite effective in sourcing reliable suppliers and in negotiating the best available quality and price.

\section{CONCLUSION}

The literature investigation provided a theoretical perspective of the ideal purchasing situation, and the empirical study provided insight into how the theory may be applied in practice.

The role of food specifications in the procurement function was stressed throughout the study. The catering managers had to determine their exact purchasing needs and specifications had to be drawn up before any procurement functions took place.

Good communication between the central purchasing department of an organisation, the various unit managers and the suppliers are of the utmost importance.

\section{REFERENCES}

BAILY, P, FARMER, D, JESSOP, D \& JONES, D (1994): Purchasing principles and management. 7th ed. London. Pitman. HUGO, WMJ \& VAN ROOYEN, DC (1990): Purchasing and materials management. 2nd ed. Pretoria. Van Schaik.

HUGO, WMJ, VAN ROOYEN, DC \& BADENHORST, JA (1997): Purchasing and materials management. 3rd ed. Pretoria. Van Schaik.

KOTCHEVAR, LH \& DONNELLY, R (1994): Quantity food purchasing. 4th ed. New York. Macmillan.

LYSONS, CK (1993): Purchasing. 3rd ed. London. Pitman. PAYNE-PALACIO, J \& THEIS, M (1997): West's and Wood's introduction to foodservice. $8^{\text {th }}$ ed. London. Prentice-Hall. SPEARS, MC (1995): Foodservice organizations: a managerial and systems approach. 3rd ed. Englewood Cliffs, NJ. Prentice Hall.

STEFANELLI, JM (1992): Purchasing selection and procurement for the hospitality industry. 3rd ed. New York. Wiley. WATKINS, C (1995): How you can help your customers write better specifications. Foodserv Distr (Feb):30-34. 